\title{
The effect of non-performing financing and financing to deposit ratio on Islamic banks financing in Indonesia
}

\author{
Gupita Permataningayu ${ }^{1}$, Siti Mahdaria ${ }^{2 *}$ \\ ${ }^{1}$ Magister of Literature, Gajah Mada University, Sleman, Yogyakarta, Indonesia \\ ${ }^{2}$ Asean Business Institute, Universitas Islam Indonesia, Yogyakarta, Indonesia \\ *Correspondent author: sitimahdaria@gmail.com
}

\begin{abstract}
Purpose: This study aims to analyze the effect of NPF (non-performing financing) and FDR (financing to deposit ratio) to the volume of financing in Indonesia Islamic Banks with third-party funds as a mediating variable. This research is a quantitative research.
\end{abstract}

Methodology: The populations in this study are Bank Indonesia Publication Reports and other references from journals, research, internet, etc. Sampling was done by purposive sampling method Secondary data collection method used is documentation method. Data analysis techniques used in this research is the technique of mediation regression analysis, which uses multiple causal step method.

Findings : The results show that NPF (non-performing financing) does not affect the volume of financing in Islamic commercial banks in Indonesia, FDR (financing to deposit ratio) does not affect the volume of financing in Islamic commercial banks in Indonesia, NPF (non-performing financing) has no effect on DPK (third party funds), FDR (financing to deposit ratio) has no effect on DPK (third party funds), DPK (third party funds) has a positive effect on the volume of financing in Islamic commercial banks in Indonesia, DPK partially mediates the effect of NPF (non-performing financing) to the volume of financing Islamic banks in Indonesia, DPK perfectly mediates the effect of FDR (financing to deposit ratio) to the volume of financing Islamic banks in Indonesia.

Originality/Contribution: This is the first study to used Islamic banks selected for this research are Bank Muamalat Indonesia, Bank Syariah Mandiri, Bank Syariah Mega Indonesia and the data are taken from the tri-monthly report.

Keywords: Non performing financing (NPF), financing to deposit ratio (FDR), third-party funds (DPK), volume of financing, Islamic bank

Cite this:

Permantaningayu, G. \& Mahdaria, S. (2019). The Effect of Non-Performing Financing and Financing to Deposit Ratio to Volume of Financing of Islamic Banks in Indonesia. Asian Journal of Islamic Management, 1(1), 28-37. DOI: 10.1108/AJIM.vol1.iss1.art3
Article History

Received, 19 February 2019

Revised 1, 13 March 2019

Revised 2, 27 March 2019

Accepted, 15 May 2019 


\section{Introduction}

Bank is a financial institution which serves as a financial intermediary between the parties who have excess funds (surplus units) and those who lack funds (deficit units) thus, the capacity is called volume of financing. (Ahmad, 1994). Through banks, the excess funds are distributed to the parties in need and provide benefits for both parties. Banks accept deposits from the public (third-party funds) and then distribute them back in the form of credit. (Karim, 2006). Banks play important role in developing countries such as Indonesia, not only act as a source of financing but also to influence the business cycle in the overall economy (Pratama, 2010).

According to Nugroho, (2009), banking credit and financing can make a significant contribution to Indonesian economy as in the following excerpt. Banks are not only the major source of funding for small, medium as well as large corporations, they also determine the business cycle of the economy as a whole. For example, in Indonesia during 2001-2004, the flows of credit from the banking sector contributed on average about 77 percent of total financing from major financial institutions (banks, bond markets, and stock markets). As a result, the rise and fall of banks have strong correlation with economic booms and busts in Indonesia.

One of the banking company's efforts to facilitate lending or financing to the community is to collect funds from third parties. Availability of third-party funds raised from the public and a good credit risk assessment create a bigger opportunity for a bank to distribute funds to people in need through credit or financing.

Funds distributed to the public in the form of financing are then used for working capital that can drive the economy of the community. However, in fact, the decision of banking credit has many potential risks. Based on Islamic Banking Development Report of 2012 published on the official website of Bank Indonesia, the assessment of the risk profile of BUS (Islamic banks) in Indonesia during the year 2012, shows that the percentage of BUS which has a risk profile Moderate to High reached $9.1 \%$, while others have profile Moderate risk $(90.9 \%)$. The amount increased compared with BUS risk profile during 2011. The risk that significantly affects the risk profile of the overall Islamic banks is the credit risk. It is the likelihood of an event that is not profitable for banks. Therefore, lending or financing by banks should be analyzed carefully so that the financing provided can be restored in accordance with the agreements that have been agreed upon. (Harmanta \& Ekananda, .2005)

Credit risk or financial risks that may be faced by Islamic banks are related to internal and external factors. External factors cover the debtors who are unable to pay loans and the economic situation of a country. Internal factors which leading to the possibility of greater credit risk is the health of banks. (Galih, 2011).

The healthiness of a bank also reflects the bank's performance. Logically, if the performance of the bank is good, it will be assessed as healthy. Performance is a reflection of the company's ability in managing and allocating resources. The performance of Islamic banking can be seen from the financial statements that are made each period. Financial performance measurement in this study uses financial ratios NPF (non-performing financing) and FDR (financing to deposit ratio). These are chosen as a proxy for financial performance because they are the best at reflecting Islamic commercial bank's soundness. NPF (non-performing financing) is the presentation of non-performing loans with the criteria substandard, doubtful, and bad credit of total loans issued by banks (Yuda \& Meiranto 2010; Khatimah, 2009). FDR (financing to deposit ratio) is a ratio that describes the level of bank liquidity. The term NPF (nonperforming financing) and FDR (financing to deposit ratio) are used in Islamic banking, while in conventional banking, the terms are known as NPL (nonperforming loans) and LDR (loan to deposit ratio). (Alamsyah, et al. 2005:. Haque, et al. 2009; Ebrahim, M.S \& Joo, T. (2001)).

A few studies concerning the factors that affect the distribution of funds in the banking system have been conducted. Previous studies were conducted to examine the effect on the disbursement of funds directly, not through third-party funds (DPK). Most subjects of the studies were conventional banking. Research results also varied. A research conducted by Yuda \& 
Meiranto (2010) stated that NPL (nonperforming loans) had no significant effect on total outstanding loans. Meanwhile, a research conducted by Soedarto (2004) revealed that NPL had a positive effect on lending.

In contrast, Pratama (2010) revealed that NPL had a negative effect on bank credit.Another research conducted by Anindita (2011), indicated that the LDR had no significant effect on SMEs lending, and by Giannini (2013), whose result indicated that FDR had a negative effect on maharajah financing.

Furthermore, a similar research conducted by Whidaningayu (2014) concluded that DPK has a significant effect in mediating NPF to the volume of financing meanwhile has no significant effect in mediating FDR.

Based on the phenomenon above, this study intends to test the effect of independent variables which include non-performing financing (NPF), and financing to deposit ratio (FDR) on the dependent variable volume of Islamic commercial bank financing through third-party funds (DPK) as a mediating variable.

This research provides benefits theoretically and practically. Theoretically, it would make a significant contribution to the field of accounting, especially regarding NPF, DPK, FDR, and volume financing of Islamic bank in Indonesia. Furthermore, it can be a reference for other researchers to conduct further research.

Practically, management of Islamic banks may take advantage of the research findings as they can be a reference in making decisions regarding the provision of financing or loan related to the level of liquidity and financial problems faced by banks. Consequently, the performance of Islamic banks may increase which in turn be able to convince people to deposit funds. Public also may take advantage of the research results as the research provides the information need whether Islamic banks are a safe place to put savings.

\section{Literature Review and Hypothesis Development}

Management's attitude towards the application of an accounting standard related to its interests on the disclosure of accounting information that describes the financial performance in the form of financial reporting. Theory-decision usefulness of accounting information is reflected in the form of rules that must be met by the components of financial reporting in order to be useful in the context of economic decision making. SFAC No. 8 clearly states the main objectives of financial reporting and the qualitative characteristics of financial information. (Pratiwi, 2010).

Business Activities of an Islamic Bank, among others are stipulated in the Act - Law of the Republic of Indonesia Number 10 of 1998 on Amendment - Act No. 07 of 1992 concerning Banking. Article 1 number (12) and (13) of Law 10 of 1998 states that financing based on Sharia Principles is the provision of cash or equivalent, based on agreements between the Bank and another party requiring the financed party to return the money or the bill after a certain period in exchange or for the results. (Yaya, et al. 2009)

Sharia is agreement rules based on Islamic law between the Bank and other parties for the financing of the fund or business activities, or other activities in accordance with Sharia, among other financing based Principles of sharing-profit (modaraba), financing based on principle of equity fund (Musharaka), The principle of buying and selling goods with profit (Murabaha), or the financing of capital goods which based on the principle of pure rental without option (Ijarah), or by the transfer of ownership of the leased item of the Bank by the other party (Ijara was qi tina).

Technical arrangements and operations of products Islamic transactions conducted by Islamic banks are already regulated by the Dewan Syariah Nasional (National Sharia Board) MUI (Indonesian Ulama Council). It also gives a distinct advantage for Indonesia in the development of Islamic banking in comparison with other countries, because the fatwa regulation is set solely by the DSN. 
According to Law No. 7 of 1992 as amended by Law No. 10 of 1998, financing based on the principles of Sharia is to provide cash or its equivalent and it is based on agreements between the parties funded to reimburse the bills after a certain period by reward or profit sharing. Financing is one of the bank's main tasks, namely providing facilities for the provision of funds to meet the needs of the parties who are a deficit. The analysis of bank lending regulation should be guided by the principle of $5 \mathrm{C}$ and $3 \mathrm{R}$, namely character, collateral, capital, capacity, condition, and return, repayment, and risk. Credit assessment must meet several criteria, namely credit safety, which means to be truly trusted that the loan can be paid back, the intended use of credit (Suitability) means that the credit will be used for the purposes that are in line with the interests of the public, or at least not against the existing rules, and beneficial (profitable) means the credit would be favorable loans for banks and for customers. (Ahmad \& Ahmad, 2003)

\section{Third-Party Fund (DPK)}

A third party fund is a source of bank funds from the community as a customer in the form of demand deposits, savings, and time deposits. Under Law No.10 of 1998, it can be said that the amount of credit depends on a number of deposits that can be collected by banks. Meanwhile, Bank Indonesia Regulation No. 10/19/PBI/2008 explains, "bank deposits, hereinafter is referred to as DPK, is the bank's liabilities to residents and non-residents in rupiah and foreign exchange". Generally, funds raised by banks from the public will be used for financing the real sector through lending (Warjiyo in Galih, 2011). Third party funds consist of Current Accounts (Demand Deposit), Saving (Saving Deposit) and deposits (time deposits). (Nurjaya, 2011).

\section{Nonperforming Financing (NPF)}

According to Yuda \& Meiranto (2010), NPL is the presentation of non-performing loans with the criteria substandard, doubtful, and loss of total loans issued by banks. Suhardjono (2003) mentioned that, the notion of credit/financing problems is a situation where a customer is not able to pay some or all of obligations to the bank as approved in the credit agreement. NPL term reserved for conventional banks, while the NPF term is for Islamic banks.

Bank Indonesia (PBI No. 15/2/PBI/2013) stipulates that a good quality of financing is when the amount of financing problems (non-performing financing) reach a maximum of $5 \%$ of the total financing provided (Nikensari et al, 2012).

\section{Financing to Deposit Ratio (FDR)}

Financing to deposit ratio (FDR) is the ratio between the amount of financing provided by the bank with third party funds (DPK) received by the bank. FDR is determined by the ratio between the amount of financing provided with public funds collected which cover demand deposits, savings and time deposits. FDR states how far the bank's ability to repay the withdrawal of funds by depositors by relying on loans as a source of its liquidity. (Budiawan, 2008).

According to Bank Indonesia, (PBI No. 15/41/DKMP dated October 1, 2013) FDR figure should be around $78 \%-92 \%$. The higher this ratio, the lower the capacity of the bank's liquidity. This is because the amount required to finance the loan becomes larger.

\section{Relationship between NPF and volume of financing}

The higher the ratio of NPF, the worse the quality of Islamic bank financing. In other words, NPF high ratios result in smooth operations of Islamic banks to be disturbed, so that the soundness of banks decreases. Due to the high NPF, a bank should provide greater reserves, which in turn erode the bank's capital although the amount of capital greatly affects the amount of credit or finance expansion. Consequently, the bank will scrutinize its financing process to avoid the risk of financing problems. This is because the potential for financing may not be collectible. (Kasri \& Kassim, 2009; Pradana,\& Sampurno, 2013 ).

$\mathrm{H}_{1}$ : NPF has a negative effect on the volume of financing of Islamic Banks in Indonesia. 


\section{Relationship between FDR and Volume of Financing}

FDR is a factor to measure the health of banks on liquidity because FDR deals with the distribution of funding, bank loans to meet its short-term obligations, repaying all depositors who withdraw funds at any time, and granting the proposed credit. From this, the researcher hypothesizes that FDR has a negative effect on the volume of financing. The volume of Financing is the capacity amount of bank to facilitate the needs of the parties who are deficit units. The facilities come in shape of Murababa, salam, is Tisha, qardh, financing, and Sarah. (Pradana \& Sampurno, 2013)

$\mathrm{H}_{2}$ : FDR has a negative effect on the volume of financing of Islamic Banks in Indonesia.

\section{Relationship between NPF and DPK}

Previous research that examines the influence of NPF to third-party funds has been done. One of which is the research conducted by Mardiansyah (2004), which examined the determinants of fund collection and distribution of Islamic banking. The research results indicate that the NPF had a negative and significant effect on DPK. Rising financing problems would provide a disincentive to the willingness of a rational society to deposit funds in Islamic banks. High NPF caused depositors would withdraw their funds due to fear of Islamic bank failure (Pradana \& Sampurno,, 2013)

$\mathrm{H}_{3}$ : NPF has a negative effect on third-party funds (DPK) in Islamic Banks in Indonesia.

\section{Relationship between FDR and DPK}

A research conducted by Nasution (2003) showed that the credit management of Islamic banks will affect the liquidity of the bank itself which in turn affect funding from third parties. Another research conducted by Andriyanti and Wasilah (2010) who found that FDR did not have a significant impact on one-month deposits mudharabah. The higher this ratio, the lower the ability of bank liquidity. So it means the number of depositors who withdraw their funds will increase. This will also affect the depositors in choosing where to collect the funds. The fourth hypothesis is formulated as follows:

$\mathrm{H}_{4}$ : FDR has a negative effect on third-party funds (DPK) Islamic Banks in Indonesia.

\section{Relationship between DPK dan Volume of Financing}

One of the activities of a bank after collecting funds from the public is distributing the funds to the people in need, in the form of loans or financing. So the higher the level DPK of an Islamic bank, the higher the amount of financing.

$\mathrm{H}_{5}$ : DPK has a positive effect on the volume of sharia bank financing in Indonesia

\section{Relationship between NPF, FDR, DPK, and Volume of Financing}

One of the activities of a bank after collecting funds from the public funds are channeled back to the people in need, in the form of loans or financing. So, the higher the level of DPK of an Islamic bank, the higher the amount of financing. Based on this, the sixth hypothesis is formulated as follows:

$\mathrm{H}_{6 a}$ : DPK mediates the effect of NPF on the volume of financing of Islamic Banks in Indonesia

$\mathrm{H}_{6 \mathrm{~b}}$ : DPK mediates the effect of FDR on the volume of financing Islamic Banks in Indonesia

\section{Research Method}

This research is a quantitative study on Islamic banking in Indonesia using secondary data analysis. The data used in this study is Bank Indonesia Publication Reports and other references 
from journals, research, the internet (www.bi.go.id), and so on related to this research. (Ghozali, 2005).

In this study, there are two independent variables, namely non-performing financing (NPF), and financing to deposit ratio (FDR). The dependent variable is named the volume of financing in Islamic banking. Mediating variables, namely third-party funds (DPK). (Febrianto, 2013; Budiawan, 2008).)

The population is Islamic banks in Indonesia. The samples in this study are taken using purposive sampling method, the overall population is re-elected based on the following criteria: a). Status as a commercial Islamic bank is not a Business Unit., b). Publish quarterly financial statements within the period 2010-2014. Therefore, data collection is done by way of documentation, namely the collection of data derived from the tri-monthly report of the company being studied.

The type of data in this research is secondary data. The secondary data are from the financial statements of Islamic banks. This study uses a time lag or a time difference called a quarterly. The reason of using the time lag is because prior period financial data (NPF and FDR) is assumed to be used to predict the DPK and financing volume in the research quarter.

\section{Research Analysis and Results}

The object of this study is Islamic banks in Indonesia. The selection is used purposive sampling method Therefore, Islamic banks selected for this research are Bank Muamalat Indonesia, Bank Syariah Mandiri, Bank Syariah Mega Indonesia. The data are taken from the tri-monthly report.

Classical assumption test result (H1-H6):

a. Normality. Based on the results of data analysis with SPSS for Windows, the value asymp. sig. (2-tailed) of the Kolmogorov-Smirnov test for unstandardized residual variable $Z$ that amounts to 0.265 greater than the value of alpha $(\alpha)$ which is 0.05 . So it can be stated that the value of the regression residuals is normally distributed.

b. Heteroskedasticity. Based on the results of the regression analysis with residual value (e) as the dependent variable, significance value of each variable tested has greater value than the value of alpha $(\alpha)=0.05$. Based on these data we can say that there are no symptoms of heteroscedasticity in the regression model.

c. Multicollinearity. Based on the test results Variance Inflation Factor (VIF) with SPSS for Windows, it is known each tested variable has a VIF value that is less than 10 . Therefore it can be declared, no symptoms multicollinearity in the regression model.

d. Autocorrelation test. The result of H1-H6 shows the value of DW is at dU up to 4-dU. Thus, it can be concluded that there is no autocorrelation in this model.

Testing significance of the effect of independent variables on the dependent variable partially uses the t-test. Based on the regression output, $\mathrm{t}$ NPF is 1.099, less than the $\mathrm{t}$ table value at 1.661. The test of NPF results, sig. $t$ equal to 0.274 greater than the value of alpha $(\alpha)=0.05$. Therefore it can be concluded that NPF variables have no effect on the volume of Islamic commercial bank financing. Thus, the first hypothesis which states that the NPF has a negative effect on the volume of financing Islamic banks in Indonesia is rejected.

Based on the regression output, FDR obtained $t$ value is 0.311 , less than the $t$ table which is 1.661. FDR test resulting in sig. $t$ equal to 0.757 greater than the value of alpha $(\alpha)=0.05$. Based on these results, it can be concluded that FDR variable has no effect on the volume of Islamic commercial bank financing. Thus, the second hypothesis which states that the FDR has a negative effect on the volume of financing Islamic banks in Indonesia is rejected.

Through statistical calculations, the coefficient determination Adjusted R Square (Adj. R2) obtained is 0.873 , meaning that 87.3 percent of the variation changes in DPK (third party 
fund) can be explained by the variable changes of NPF and FDR, while the rest 12.7 percent is explained by other unexamined variables. (Arisandi, 2007).

Next is testing the significance of the effect of independent variables on the dependent variable partially using the $t$ test. Based on the regression output, $t$ NPF is 0.096 , less than the $t$ table value at 1.661. The test of NPF results, sig. $t$ equal to 0.350 is greater than the value of alpha $(\alpha)=0.05$. Therefore, it can be concluded that the NPF variable has no effect on DPK. Thus, the third hypothesis which states that the NPF has a negative effect on the DPK of Islamic banks in Indonesia is rejected.

Based on the regression output, tFDR is -.022, less than the $t$ table which is 1.661. FDR test resulting in sig. $t$ equal to 0.829 , greater than the value of alpha $(\alpha)=0.05$. Based on these results, it can be concluded that FDR variable has no effect on the third-party fund (DPK) in Islamic Bank. Thus, the fourth hypothesis which states that the FDR has negative effect on the DPK in Islamic banks in Indonesia is rejected

Through statistical calculations, the coefficient determination Adjusted R Square (Adj. R2) obtained is 0.998 , meaning that 99.8 percent of the variation changes in Volume Financing can be explained by the variable changes of NPF FDR, and DPK while the rest 0.2 percent is explained by other unexamined variables.

Next is testing the significance of the effect of independent variables on the dependent variable partially using the t test. Based on the regression output, t DPK is 209.668, far greater than the $t$ table value at 1.661. The test of DPK results, sig. $t$ equal to 0.000 less than the value of alpha $(\alpha)=0.05$. It can be seen that $\mathrm{t}$ has positive coefficient direction, therefore it can be concluded that the DPK variables positively affect DPK. Thus, the third hypothesis which states that the DPK has a positive effect on the Volume Financing of Islamic banks in Indonesia is accepted.

Results for the third equation regression analysis shown in table 21. Testing the significance of the influence of the independent variables and mediating on the dependent variable partially uses the t-test, the test results for each variable as follows:

Based on the regression output, obtained $t$ value of NPF obtained is 3.421, greater than the $\mathrm{t}$ table value which is 1.661. The output regression also shows that sig. $\mathrm{t}$ equal to 0.001 less than the value of alpha $(\alpha)=0.05$. Therefore, with positive coefficient direction, it can be concluded that the NPF variable affects the volume of Islamic commercial bank financing.

Based on the regression output, obtained FDR variable $t$ value is 11.230. It is greater than the $t$ table value which is 1.661. The regression output also shows that sig. $t$ is 0.000 , less than the value of alpha $(\alpha)=0.05$. Based on these results and with positive coefficient direction, it can be concluded that FDR variable affects the volume of Islamic commercial bank financing

Based on the regression output DPK variable values obtained $t$ is 209.668 , greater than the $\mathrm{t}$ table value which is 1.675. The output regression also shows that sig. $\mathrm{t}$ is 0,000 which is less than the value of alpha $(\alpha)=0.05$. Therefore, it can be seen that thas a way with a positive coefficient, it can be concluded that DPK variable positively affects the volume of Islamic commercial bank financing.

The unstandardized coefficient in the third equation, namely NPF against financing volume by including the variable DPK as a mediating variable of 0.016 with 0.001 significance, means there is a positive effect on the volume of financing NPF Islamic bank in Indonesia, and becomes partially mediates the effect of NPF with Volume of financing. The unstandardized coefficient on the FDR to the financing volume by including variable DPK as a mediating variable is 0.008 with 0.000 significance, means there is a positive influence on the volume of financing FDR in Islamic banks in Indonesia.

The above analysis proves that NPF independent variable does not affect the mediating variable (DPK). So, that DPK variable partially mediates the effect of NPF on the variable financing volume and DPK variable perfectly mediates the effect of FDR on the variable volume of financing. 


\section{Conclusion}

Based on the results of research and discussion, we can conclude that NPF (non-performing financing) does not affect the volume of financing in Islamic commercial banks in Indonesia. FDR (financing to deposit ratio) does not affect the volume of financing in Islamic commercial banks in Indonesia. NPF (non-performing financing) has no effect on DPK (third party funds). FDR (financing to deposit ratio) has no effect on DPK (third party funds). DPK (third party funds) has a positive effect on the volume of financing in Islamic commercial banks in Indonesia. DPK partially mediates the effect of NPF (non-performing financing) to the volume of financing Islamic banks in Indonesia. DPK perfectly mediates the effect of FDR (financing to deposit ratio) to the volume of financing Islamic banks in Indonesia.

This study has limitations, including the characteristics of Bank Mega Syariah Indonesia are different consequently, the research findings could not be generalized. Also, restrictions and the determination of the criteria of the research subject, causing the subject only comprises five Islamic banks in Indonesia. This has an impact on the number of samples which amounts to 100 samples so the results are less representative.

Having conducted this research, there are few suggestions for further research, including it is recommended that further research increases the number of samples to be adapted to the needs of the information and data needed, so that the results obtained are representative. Moreover, It is recommended that further research use other variables such as CAR (Capital Adequacy Ratio), ROA (return on assets), and ROA as a proxy of the performance of Islamic banks in relation to financing volume.

\section{References}

Ahmad, N.H \& Ahmad, S.N.,. (2003). Key factors influencing credit risk of islamic bank: A Malaysian case. University Utara Malaysia. Retrieved from: file://C:/Users/User/AppData/Local/Packages/Microsoft.MicrosoftEdge_8wekyb3d8b bwe/TempState/Downloads/Key_factors_influencing_credit_risk_of_Islamic_ban\%20(1). pdf

Ahmad, Z. (1994). Islamic banking: State of the art. Islamic Economic Studies, The Islamic Research and Training Institute (IRTI), vol. 2, pages 1-33. Retrieved from: http://www.irti.org/English/Research/Documents/IES/148.pdf

Andriyanti, A. W. (2010). Faktor-faktor yang mempengaruhi jumlah penghimpunan dana pihak ketiga (deposito mudharabah 1 bulan) BankMmuamaIat indonesia. Jurnal SNA XIII Purwokerto .

Anindita, I. (2011). Analisis pengaruh tingkat suku bunga, CAR, NPL, dan LDR terhadap penyaluran kredit umkm (studi pada bank umum swasta nasional periode 2003-2010). Thesis. Universitas Diponegoro Semarang . Retrieved from: http://eprints.undip.ac.id/28511/1/skripsi_full_text.pdf

Arisandi, D. (2007). Analisis faktor penawaran kredit pada bank umum di indonesia.Theisis. Jurnal Fakultas Ekonomi Universitas Gunadarma .

file:///C:/Users/User/AppData/Local/Packages/Microsoft.MicrosoftEdge_8wekyb3d8b bwe/TempState/Downloads/76167093-Analisis-Faktor-Penawaran-Kredit-Pada-BankUmum-Di\%20(1).pdf

Bank Indonesia. (2013). Peraturan Bank Indonesia nomor 15/2/PBI/2013 tanggal 20 Mei 2013 tentang penetapan status dan tindak lanjut pengawasan bank umum konvensional. Retrieved 09 Desember 2013, from 
http://www.bi.go.id/web/id/Peraturan/Perbankan/PBI_15_2_PBI_2013.htm?mweb=fal se

Budiawan. (2008). Analisis faktor-faktor yang mempengaruhi penyaluran kredit pada bank perkreditan rakyat (studi kasus pada BPR di wilayah kerja BI banjarmasin). Universitas Diponegoro.

Ebrahim, M.S \& Joo, T. (2001). Islamic banking in Brunnei Darussalam. International Journal of Social Economics, 28 (4) , 314-337. https://doi.org/10.1108/03068290110357708

Nasution, C.S. (2003). Manajemen kredit syariah bank muamalat. Kajian Ekonomi dan Keuangan $.7(3)$

Harmanta \& Ekananda, M.. (2005). Disintermediasi fungsi perbankan di indonesia pasca krisis 1997: faktor permintaan atau penawaran kredit, sebuah pendekatan dengan model disequilibirium. Buletin Ekonomi Moneter dan Perbankan . 8(1), 51-78. DOI: https://doi.org/10.21098/bemp.v8i1.128

Febrianto, D.W \& Muid, D. (2013). Analisis pengaruh dana pihak ketiga, LDR, NPL, CAR, ROA, dan BOPO terhada jumlah penyaluran kredit. Diponegoro Journal of Accounting, 2 (4), 1 11. Retrieved from: . http://ejournal-s1.undip.ac.id/index.php/accounting

Galih, T. (2011). Pengaruh pihak ketiga, CAR, NPL, dan LDR, terhadap jumlah penyaluran kredit pada bank di Indonesia. Thesis. Universitas Diponegoro. Retrieved from: https://core.ac.uk/download/pdf/11728342.pdf

Ghozali, I. (2005). Aplikasi analisis multivariate dengan program SPSS. Semarang: Badan Penerbit Universitas Diponegoro.

Giannini, N.G. (2013). Faktor yang mempengaruhi pembiayaan mudharabah pada bank umum syariah di Indonesia. Accounting Analysis Journal. 2(1), 96-103. DOI: https://doi.org/10.15294/aaj.v2i1.1178

Alamsyah, H, Zulverdi, D., Gunadi. I., Idris. R.Z., Pramono, B (2005). Banking disintermediation and its implication for monetary policy: the case of Indonesia. Buletin Ekonomi Moneter dan Perbankan, 7 (4)., 499-521. DOI: https://doi.org/10.21098/bemp.v7i4.122

Haque, A., Osman, J.\& Ismail, A.Z., . (2009). Factors influences selection of islamic banking: a study of malaysian customer preferences. American Journal of Applied Sciences, 6 (5), 922-928. DOI:10.3844/ajassp.2009.922.928

Karim, A. (2006). Bank islam analisis fiqih dan keuangan. Jakarta: Raja Graffindo Persada.

Kasri, R.A \& Kassim, S. (2009). Empirical determinants of saving in the islamic banks: evidence from indonesia. The Journal of King Abdulariz University, 22 (2) , 181-201. Retrieved from: https://www.kau.edu.sa/Files/121/Files/67320_22-2-Kasri-7.pdf

Khatimah, H. (2009). Analisis faktor-faktor yang mempengaruhi penyaluran dana perbankan syariah di Indonesia sebelum dan sesudah kebijakan akselerasi perbankan syariah tahun 2007/2008. Optimal, Jurnal Ilmiah Ekonomi, Manajemen dan Kewirausahaan, 3(1), 1-14.

Retrieved from:

http://jurnal.unismabekasi.ac.id/index.php/optimal/article/view/680/566

Mardiansyah, A. (2004). Analisis faktor-faktor penentu penghimpunan dan penyaluran dana perbankan syariah beserta peramalannya. Thesis. Institut Pertanian Bogor. https://repository.ipb.ac.id/jspui/bitstream/123456789/15654/1/H04AMA.pdf 
Nikensari, S.I., Sugiarti, D \& Sariwulan, T. (2012). Pembiayaan mudharabah dan kaitannya dengan NPF dan bagi hasil. Jurnal Econo Sains, 10 (2). 231-250. DOI: https://doi.org/10.21009/econosains.0102.06

Nugroho, R. Y. Y (2009). Analisis faktor-faktor penentu pembiayaan perbankan syariah di indonesia: aplikasi model vector error correction. Thesis. Institut Pertanian Bogor. Retrieved from:

file://C:/Users/User/AppData/Local/Packages/Microsoft.MicrosoftEdge_8wekyb3d8b bwe/TempState/Downloads/risyuwono-3\%20(1).pdf

Nurjaya, E. (2011). Analisis pengaruh inflasi, SBIS, NPF, dan DPK terhadap pembiayaan murabahah pada bank syariah di Indonesia. Thesis. Universitas Islam Negeri Syarif Hidayatullah Jakarta. Retrieved from:

file:///C:/Users/User/AppData/Local/Packages/Microsoft.MicrosoftEdge_8wekyb3d8b bwe/TempState/Downloads/ENDANG\%20NURJAYA-FEB\%20(1).pdf

Pradana, Y \& Sampurno, R.D. (2013). Analisis pengaruh LDR, CAR, ROA, dan faktor eksternal perbankan terhadap volume KPR pada Bank Persero periode 2008-2012. Diponegoro Journal of Management, 2 (3), 1-15. Retrieved from: http:/ / ejournals1.undip.ac.id/index.php/dbr

Pratama, B. (2010). Analisis faktor-faktor yang mempengaruhi kebijakan penyaluran kredit perbankan (studi pada Bank Umum di Indonesia periode tahun 2005-2009). Jurnal Bisnis Strategi, 19(2), 135-148. DOI:. https://doi.org/10.14710/ibs.19.2.135-148

Pratiwi, A.I. (2010). Decision usefulness: berdasarkan teori keputusan dan teori investasi. Jurnal Ilmiah Bisnis dan Ekonomi Asia Vol. 5 (1). Retrieved from: 100-111.

file:///C:/Users/User/AppData/Local/Packages/Microsoft.MicrosoftEdge_8wekyb3d8b bwe/TempState/Downloads/82223702-Decision-Usefulness-Berdasarkan-TeoriKeputusan-Dan-Teori-Investasi\%20(1).pdf

Soedarto, M. (2004). Analisis faktor-faktor yang mempengaruhi penyaluran kredit pada bank perkreditan rakyat (studi kasus pada BPR di wilayah kerja BI Semarang). Thesis. Universitas Diponegoro Semarang. Retrieved from: http:/ / eprints.undip.ac.id/9685/1/2004MM3126.pdf

Suhardjono. (2003). Manajemen perkreditan. Jakarta: UPPAMPYKPN.

Whidaningayu, E. (2015). Analisis pengaruh non performing financing dan financing to deposit ratio terhadap volume pembiayaan pada perbankan syariah di indonesia dengan dana pihak ketiga sebagai variabel mediasi. Jurnal Riset Keuangan dan Akuntansi, 1 (1), 1-15. DOI: https://doi.org/10.25134/jrka.v1i01.430

Yaya, R., Martawireja, A., \& Abdurahim, A. (2009). Akuntansi perbankan syariab' teori dan praktike kontemporer. Jakarta: Salemba Empat.

Yuda. I, M, P., \& Meiranto., W. (2010). Pengaruh faktor internal bank terhadap jumlah kredit yang disalurkan (studi empiris pada bank yang terdaftar di Bursa Efek Indonesia). Jurnal Akuntansi dan Auditing, 7 (1): 94-110. DOI: https://doi.org/10.14710/jaa.7.1.94-110 